Proceedings of the $9^{\text {th }}$ International Scientific Conference Rural Development 2019

Edited by prof. Asta Raupelienè

ISSN 1822-3230 (Print)

ISSN 2345-0916 (Online)

Article DOI: http://doi.org/10.15544/RD.2019.077

\title{
CUT-AWAY PEATLAND RE-CULTIVATION WITH FAST GROWING WOODY PLANTATIONS: COST-BENEFIT ANALYSIS.
}

\begin{abstract}
Kristaps MAKOVSKIS, Latvian State Forest Research Institute "Silava", Riga street 111, Salaspils, Latvia, kristaps.makovskis@silava.lv (corresponding author)

Dagnija LAZDINA, Latvian State Forest Research Institute "Silava", Riga street 111, Salaspils, Latvia dagnia.lazdina@silava.lv

Dina POPLUGA'Latvia University of Life Sciences and Technologies, Faculty of Economics and Social Development, Svetes street 18, Jelgava, Latvia, dina.popluga@llu.lv

In Latvia peat production is historically important economic sector, giving significant contribution to rural economic development and providing work places in rural areas, where other job opportunities are limited. Every peat extraction field has certain lifespan, based on economic, social or ecological assumptions. Every peat field could be extracted for set period of time, after which peat extraction is not feasible any more. Current legislation in Latvia requires re-cultivating of places, where mineral resources, including peat, were extracted. Aim of the study is to evaluate afforestation as one of the cut-away peatland re-cultivation possibility. Economic analysis were done for extracted peat field afforestation with birch, black alder, grey alder, pine, spruce, hybrid aspen, poplar and willow. The economic calculations were done comparing different timber products from plantations, different planting materials and plantation lifespans. Lowest investment costs for plantation establishment on cutaway peatlands are for pine and spruce plantations and highest for willow plantations. Highest revenues in plantations with 20 years rotation cycle are in poplar plantations with $0.2 \mathrm{~m}$ cuttings and lowest in grey alder plantations. In plantations with rotation cycle 40 years highest revenues are in hybrid aspen plantations and lowest in pine plantations.
\end{abstract}

Keywords: cut-away peatlands, peatland forestry, forest on peatlands, cut-away peatland management.

\section{INTRODUCTION}

In world peatlands cover around $400 \mathrm{mln}$ ha and around 200000 ha are used in peat industry, what is around $0.05 \%$ from all peatlands. In European Union (EU) peatlands cover $28.2 \mathrm{mln}$ ha and around 120,000 ha are used in peat industry, which is $0.03 \%$ (Altman, 2008). In Latvia there are more than 6800 peat deposits with total volume

Copyright (C) 2019 The Authors. Published by Vytautas Magnus University. This is an open-access article distributed under the terms of the Creative Commons Attribution License (CC BY 4.0), which permits unrestricted use, distribution, and reproduction in any medium, provided the original author and source are credited. 
about $5 \mathrm{bln}$. t, that is about $0.4 \%$ of all world peat resources and ranks in $8^{\text {th }}$ place in the world in peat quantity per country resident (Snore, 2013). Peatlands occupy 10\% of countrie's territory, with total peatland area 691,000 ha. Around 4\% from all peatlands are used in peat industry with total area 26,000 ha and 19,200 ha are released from production which is around 3\% from all peatlands (Eksperti: kūdras ieguves... 2017; Ozola, 2017). Peat industry (including peat extraction and peat substrate production) in Latvia provides around 10,000 work places, mostly in summer time and most of them in rural areas with limited other work opportunities (Klavins \& Krigere, 2016).

After peat extraction cessation erosion and nutrient leaching into watercourses may occur, therefore extracted peatland re-cultivation is recommended (Huotari et al., 2008). Natural regeneration of cut-away peatland areas is complicated and may take several decades (Groeneveld \& Rochefort, 2012). Current legislation in Latvia requires re-cultivation of places, where mineral resources, including peat, were extracted. According to legislations, following peat field re-cultivation possibilities are allowed: afforestation, farmland or berry plantation installation, watercourse or recreational areas creation (MK noteikumi Nr. 570, 2016). Cut-away peatlands are significant atmospheric carbon source (Mäkiranta et al., 2007) and afforested sites sequester atmospheric carbon (Clymo, 1984, Hytönen \& Aro, 2012, Karki et al., 2016). In Finland, Sweden and Ireland forestry is considered to be the main reuse option for cut-away peatlands (Hanell, 1996, Selin, 1999, Renou \& Farrell, 2005). Afforestation is technically easiest marketable cut-away peatlands management practice that could be implemented in Latvia.

Timber products that could be produced in plantation forest or short rotation coppice plantations (SRC) plantations on cut-away peatland are wood chips, pulpwood and roundwood. Products may differ according to forest plantation lifespan and tree species. Promising results showed wood pellet production with small scale pelletizer from different fast growing species (Makovskis et al., 2016).

Silver birch (Betula pendula) and downy birch (Betula pubescen) in longer rotation periods could be used successfully for biomass production on cut-away peatlands. (Renou et al., 2007). It is recommended to grow willow on cut-away peatlands if base material is mineral soil, peat layer is thinner than $30 \mathrm{~cm}$, soil pH is higher than 4.5 and suitable willow clone is selected (Lazdina, 2009). Two main problems for willow plantations on cutaway peatlands are related to harvesting that is possible mainly in winter time when soil is frozen and to the lack of $\mathrm{P}$ and $\mathrm{K}$ in soil (that means that fertilization of soil will be needed) (Dimitriou \& Rutz, 2014). Alder, aspen and coniferous tree species show. good results in cut-away peatland afforestation. Alder is suitable specie when quick cut-away peatland cover is needed and it could be used for growing in mixtures with other, mainly coniferous tree species. (Schaible, 1992, Renou-Wilson et al., 2008).

Because of low potassium and phosphorus concentration in peat, fertilization is recommended (Huotari et al., 2008). Positive effect in fertilization with wood ash is observed within first 1-2 years and in some cases also after 12 years (Klavina et al., 2016, Lazdina et al., 2017). Studies in Finland report positive wood ash effect on tree growing on drained peatlands even 50 years after treatment. In unfertilized plots ground vegetation consisted mostly of mosses and dwarf shrubs, while in treated with wood ash vegetation was typical to upland forest with herbs and grasses (Moilanen et al., 2002). To prevent surface from peat erosion and decomposition, ground vegetation growth and development is desirable, therefore fertilisation is recommended before planting. The aim of this study was to evaluate afforestation with different tree species in different rotation periods as cutaway peatland re-cultivation possibility. 


\section{MATERIAL AND METHODS}

In this study eight different tree species (coniferous and broad leaved) were selected for the calculations: willow (Salix viminalis.), poplar (Populus nigra.) and grey alder (Alnus incana L.) with rotation period of 20 years and hybrid aspen (Populus tremula L. x P. tremuloides Michx.), spruce (Picea abies), pine (Pinus sylvestris L.), birch (Betula pubescens.) and black alder (Alnus glutinosa) with rotation period of 40 years. In Poplar calculations two different planting materials $(0.2$ and $1.2 \mathrm{~m})$ with different planting density (1600 and 800 seedlings per hectare) were taken.

Main costs regarding plantation management on cut-away peatlands are associated with plantation establishment and production costs.

Plantation establishment costs include following cost items: planting site preparation, soil preparation before planting and planting costs. In this study it was considered that planting site, i.e. cut-away peatland, preparation costs are equal for all tree species and willows, as well it was estimated that main planting site preparation costs are associated with overgrow harvesting costs. In some cases, site preparation is not needed on cutaway peatlands, however, previous studies shows, that site preparation before afforestation is necessary and leads to growing condition improvement, what later results in better survival rates and biomass increase (Sutton 1993, Savill et al. 1997, Ryans and Sutherland, 2011). Site preparation method should be used according to specific site conditions and should be considered very carefully, because total afforestation costs will be greatly affected by the method (Renou-Wilson et al., 2008). Authors take into consideration that these costs could change between different sites, where overgrow intensity, soil bearing capacity and water level could vary, what could lead to overgrow harvesting costs changes.

Production costs includes following cost items: agrotechnical management, fertilization and harvesting. Beside these costs, in the case of hybrid aspen and poplar plantations costs for animal browsing protection were taken into account, as well as costs for poplar pruning. It was assumed that for animal browsing protection repellents are used in the first 5 years and pruning is done at $5^{\text {th }}$ year of plantation lifespan. Costs for water purification (sedimentation ponds) and site maintenance (cleaning ditches from sediments, holding the water level on the optimal hight, etc.) are not considered in calculations. Trees are planted in sites with suitable water level and after afforestation plantation is managed as forest. For better biomass growth and to ensure optimal growth conditions on cut-away peatlands fertilization is recommended. According to previous studies it was assumed that cut-away peatland should be fertilized with $5 \mathrm{t} \mathrm{ha}^{-1}$ wood ash before planting (Lazdina et al., 2017). In calculations one fertilization per plantation lifespan is foreseen (before planting), except for willows, where 5 fertilizations would be done, one before planting and then every $4^{\text {th }}$ year. Plantation productivity for grey alder, birch, pine, spruce and black alder in calculations was taken from NFI database for trees on peatlands. Wood volume for willows, poplar and hybrid aspen was taken from previous studies.

Fast growing woody plantation benefits reflect whether the plantation cultivation will bring profit or loss. In this study the economic benefit was assessed by the fallowing indicators:

- Gross profit or loss, EUR ha ${ }^{-1}$

- Gross profitability, \% 
- $\quad$ Benefit Cost Ratio (BCR)

- $\quad$ Net present value (NPV), EUR ha ${ }^{-1}$

To achieve the aim and tasks of the study, authors used statistical data from Central Statistical Bureau of Latvia (CBS), data from National Forest Inventory (NFI) and research results from previous studies.

\section{RESULTS AND DISCUSSION}

Highest total investment costs are for willow plantation establishment - $1549 \mathrm{EUR}^{-1} \mathrm{a}^{-1}$, due to high planting material costs. Lowest investment costs are for pine - $1042 \mathrm{EUR} \mathrm{ha}^{-1}$ and spruce - $1090 \mathrm{EUR} \mathrm{ha}^{-1}$ plantations, where planting material and planting costs are $31 \%$ lower than willow planting material costs (Tab.1.).

Table 1. Plantations on cut-away peatlands establishment costs

\begin{tabular}{|c|c|c|c|c|c|c|c|c|}
\hline $\begin{array}{l}\text { Rotation } \\
\text { period }\end{array}$ & Tree specie & $\begin{array}{l}\text { Planting } \\
\text { density, } \\
\text { seedlings } \\
\mathrm{ha}^{-1}\end{array}$ & \begin{tabular}{|l} 
One \\
seedling \\
price, EUR
\end{tabular} & $\begin{array}{l}\text { Planting } \\
\text { material } \\
\text { costs, } \\
\text { EUR ha }{ }^{-1}\end{array}$ & $\begin{array}{l}\text { Planting } \\
\text { costs, EUR } \\
\text { ha }^{-1}\end{array}$ & $\begin{array}{l}\text { Site preparation } \\
\text { for planting, } \\
\text { EUR ha-1 }\end{array}$ & $\begin{array}{l}\text { Unforseen } \\
\text { costs, } \\
\text { EUR ha }\end{array}$ & $\begin{array}{l}\text { Total planting } \\
\text { costs, } \\
\text { EUR ha } \text { ha }^{-1}\end{array}$ \\
\hline \multirow[t]{4}{*}{20 years } & Willow & 13000 & 0.06 & 780 & 150 & 590 & 74 & 1594 \\
\hline & Poplar $(0,2 \mathrm{~m})$ & 1600 & 0.2 & 340 & 110 & 590 & 70 & 1110 \\
\hline & Poplar $(1,2 \mathrm{~m})$ & 800 & 0.85 & 680 & 110 & 590 & 70 & 1450 \\
\hline & Grey alder & 1600 & 0.22 & 352 & 110 & 590 & 70 & 1122 \\
\hline \multirow[t]{5}{*}{40 years } & Hybrid aspen & 1600 & 0.72 & 576 & 110 & 590 & 70 & 1346 \\
\hline & Spruce & 1600 & 0.2 & 320 & 110 & 590 & 70 & 1090 \\
\hline & Pine & 1600 & 0.17 & 272 & 110 & 590 & 70 & 1042 \\
\hline & Birch & 1600 & 0.22 & 352 & 110 & 590 & 70 & 1122 \\
\hline & Balck alder & 1600 & 0.22 & 352 & 110 & 590 & 70 & 1122 \\
\hline
\end{tabular}

Such findings correspond with findings of earlier studies of the economy of wood biomass production focused on short-rotation species, such as willow and poplar, that states that these plantations require considerable large investments in plantation establishment and biomass production (Jylhä et al., 2015).

Production costs were calculated for all plantation lifespan at discount rate $2.5 \%$. It was concluded that the highest production costs for plantations with 20 years rotation cycle were characteristic for poplar plantations with $0.2 \mathrm{~m}$ cuttings - $4753 \mathrm{EUR} \mathrm{ha}^{-1}$, but the lowest - for grey alder $\left(2451 \mathrm{EUR} \mathrm{ha}^{-1}\right)$. In plantations with rotation cycle 40 years highest production costs were for hybrid aspen plantations - 6608 EUR ha $^{-1}$; and lowest - for pine plantations (2393 EUR ha-1). In hybrid aspen plantations 2 harvests could be done due the plantation lifespan, while in other tree species plantations, except willow plantations, only one harvest could be done in the end of plantation lifespan. In willow plantations harvest is possible at least every 4th year, which in total are 5 harvests 
in plantation lifespan. Harvest operation prices are the same for all tree species, except willows, where different harvest operation calculations were used (see fig. 1).

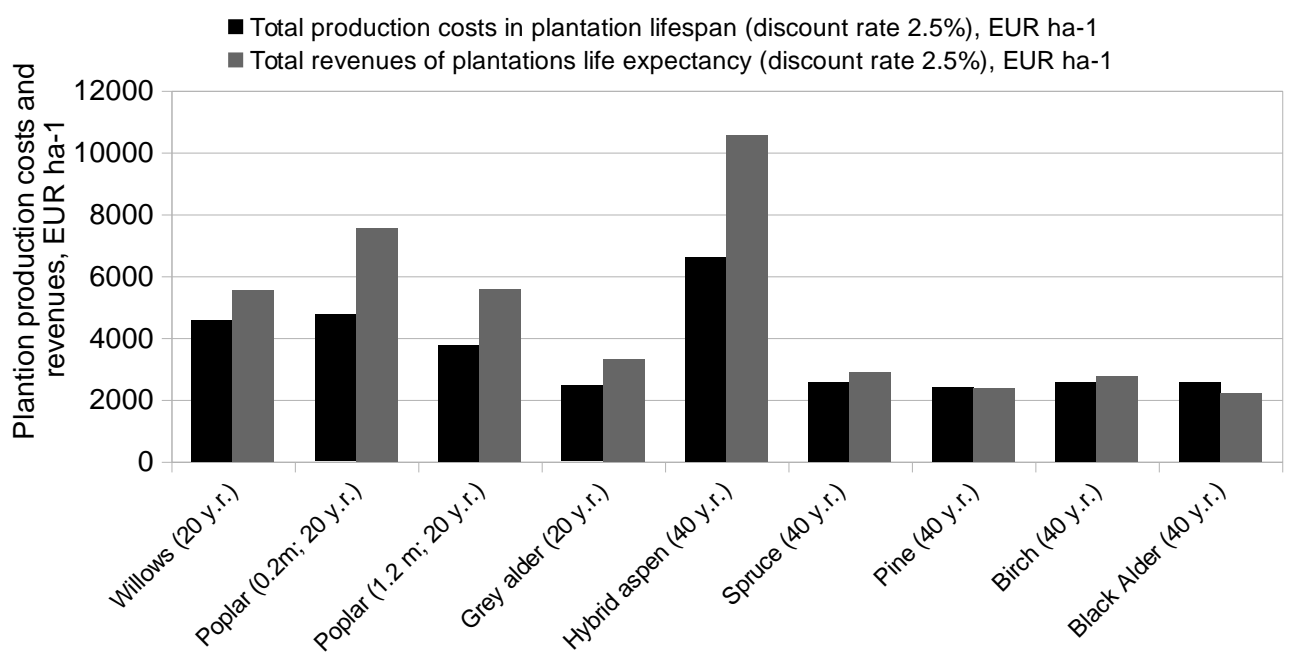

Figure 1. Total production costs and revenues for tree plantation lifespan on cut-away peatlands (discount rate 2.5\%), EUR ha ${ }^{-1}$

Revenues were calculated according to projected wood volume and nowadays timber prices. Study results show that highest revenues in plantations with 20 years rotation cycle appear for poplar plantations with $0.2 \mathrm{~m}$ cuttings - $7557 \mathrm{EUR} \mathrm{ha}^{-1}$, but lowest - in grey alder plantations (3306 EUR ha-1). In plantations with rotation cycle of 40 years the highest revenues are for hybrid poplar plantations - $10554 \mathrm{EUR} \mathrm{ha}^{-1}$; and lowest - for pine plantations (2393 EUR ha-1). Hybrid aspen plantation have 2 rotation cycles in lifespan and in each cycle wood volume is about $300 \mathrm{~m}^{3} \mathrm{ha}^{-1}$ that gives highest revenues compared with other tree species.

Positive NPV indicates that the projected earnings generated by investment exceed the anticipated costs. Investments with higher NPV will be more profitable then investments with lower NPV. It was calculated that the highest NPV value is for hybrid aspen plantations - $5348 \mathrm{EUR} \mathrm{ha}^{-1}$ and lowest for black alder - $771 \mathrm{EUR} \mathrm{ha}^{-1}$ and pine - 1031 EUR ha ${ }^{-1}$ (Fig.2). 


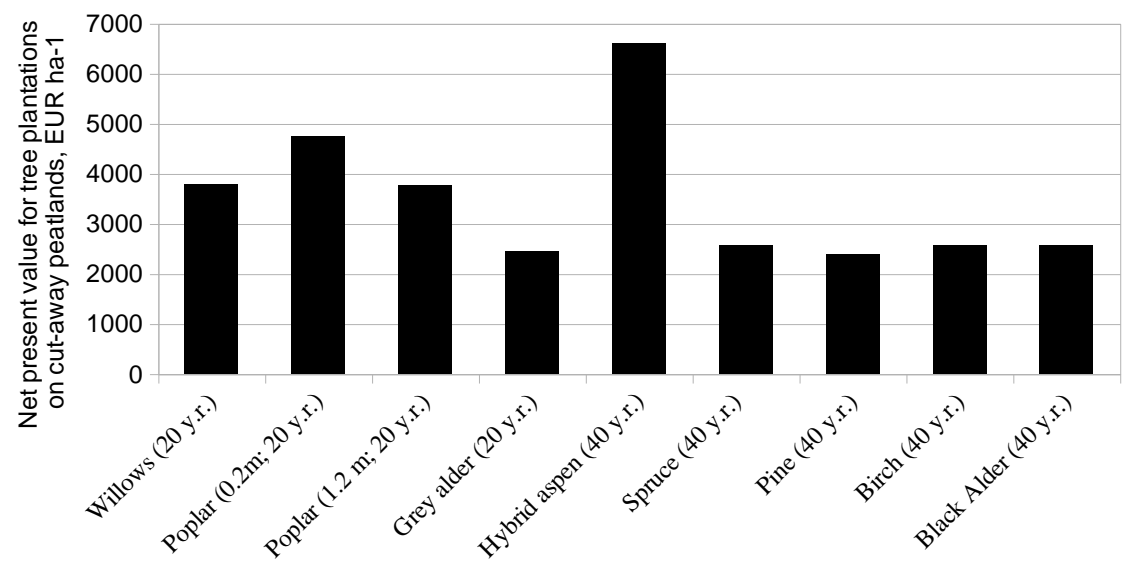

Figure 2. Net present value for tree plantations on cut-away peatlands, EUR ha- ${ }^{-1}$.

Plantations with shorter life cycle (20 years) show better NPV values then plantations with longer life cycle. Despite long rotation cycle of 40 years, hybrid aspen plantations show best NPV value and the main reason is hybrid aspen superior growth abilities what provides 2 rotation cycles in the same time span as one rotation for slower growing species.

If Benefit Cost Ratio (BCR) is greater than 1, it indicates that NPV of the plantation benefits outweigh the NPV of the costs. Highest BCR was noticed for hybrid aspen plantations -1.6 and poplar with $0.2 \mathrm{~m}$ cuttings 1.5. The species with lowest BCR are black alder -0.85 and pine -0.99 . (see. Fig. 3 ).

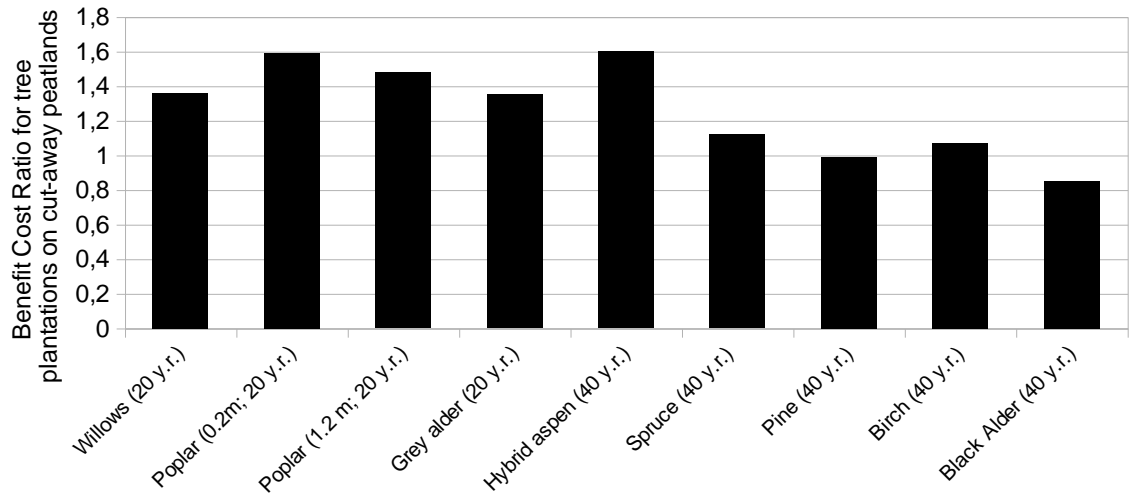

Figure 3. Benefit Cost Ratio for tree plantations on cut-away peatlands. 
Plantation establishment on cut-away peatlands with regarded tree species should be considered if the BCR value is higher than 1 . If the plantation BCR is less than 1 , the costs outweigh the benefits and plantation should be not considered as profitable investment.

\section{CONCLUSIONS}

Cut-away peatland afforestation is technically easily marketable practice and main timber products are wood chips, pulpwood and roundwood. Lowest investment costs for plantation establishment on cut-away peatlands are for pine and spruce plantations and highest for willow plantations. Highest production costs for plantations with 20 years lifespan are in poplar plantations with $0.2 \mathrm{~m}$ cuttings and lowest for grey alder plantations. In plantations with 40 years lifespan highest production costs are in hybrid aspen plantations and lowest in pine plantations. Highest revenues in plantations with 20 years rotation cycle are in poplar plantations with $0.2 \mathrm{~m}$ cuttings and lowest in grey alder plantations. In plantations with rotation cycle 40 years highest revenues are in hybrid aspen plantations and lowest in pine plantations. Plantations with shorter lifespan (20 years) show better Net Present value (NPV) then plantations with longer lifespan. Exception is hybrid aspen plantations which shows highest NPV from all tree species despite long lifespan, while black alder and pine plantations show lowest NPV. Plantation establishment on cut-away peatlands with fallowing tree species should be considered if the Benefit Cost ratio (BCR) value is greater than 1. For all plantations, except black alder and pine plantations, $\mathrm{BCR}$ ratio was greater than 1, with highest value of 1.6 for hybrid aspen plantation.

Acknowledgement. This research was funded by the European Commission within the project "Marginal lands for growing industrial crops: Turning a burden into an opportunity (MAGIC)" Horizon 2020 (H2020) grant agreement No. 727698)

\section{REFERENCES}

1. Altmann M. 2008. Socio-economic Impact of the Peat and Growing Media Industry on Horticulture in the EU: Report for EPAGMA by Co Concept, 134.

2. Clymo R. S. 1984. Sphagnum-dominated peat Bog-a naturally acid ecosystem. Philosophical Transactions of the Royal Society of London Series B: Biological Sciences 305, 487-499. https://doi.org/10.1098/rstb.1984.0072

3. Dimitriou I., Rutz D. 2014. Sustainability criteria and recommendations for short rotation woody crops - SRCplus. Assessed 17.01.2017. Available:

4. Eksperti: Kūdras ieguves biznesam noteikts l̦oti strikts rāmis. 2017. http://www.latvijaskudra.lv/lv/aktualitates/1369eksperti_kudras_ieguves_biznesam_noteikts_loti_strikts_darbibas_ramis.html. Accesed 16.01.2017. (in Latvian).

5. Groeneveld E., Rochefort L. 2012. Nursing plants in peatland restoration: on their potential use to alleviate frost heaving problems. Suo, Vol. 53 (3/4), pp. 73-85.

6. Hånell B., Svensson J., Magnusson T. 1996. Summary: Reclamation of Peat Winning Fields - A Literature Review with Special Reference to the Establishment of Forest Stands . Reports in Forest Ecology and Forest Soils, Vol. 70, 34 p.

7. Hytönen J., Aro L. 2012. Biomass and nutrition of naturally regenerated and coppiced birch on cutaway peatland during 37 years. Silva Fenn, Vol. 46 (3), pp. 377-394. https://doi.org/10.14214/sf.48 
8. Huotari N., Tillman-Sutela E., Pasanen J., Kubin,E. 2008. Ash-fertilization improves germination and early establishment of birch (Betula pubescens Ehrh.) seedlings on a cut-away peatland. Forest Ecology and Management, Vol. 255, pp. 28702875. https://doi.org/10.1016/j.foreco.2008.01.062

9. Jylhä P., Hytönen J., Ahtikoski A. 2015. Profitability of short-rotation biomass production on downy birch stands on cutaway peatlands in northern Finland. Biomass and Bioenergy, Vol. 75, pp. $272-281$. https://doi.org/10.1016/j.biombioe.2015.02.027

10. Karki S., Elsgaard L., Kandel T. P., Larke P. E. 2016. Carbon balance of rewetted and drained peat soils used for biomass production: a mesocosm study. GCG Bioenergy, Vol. 8, pp. 969-980. https://doi.org/10.1111/gcbb.12334

11. Klavina D., Pennanen T., Gaitnieks T., Velmala S., Lazdins A., Lazdina D., Menkis A. 2016. The ectomycorrhizal community of conifer stands on peat soils 12 years after fertilization with wood ash. Mycorrhiza, Vol. 26 (2), pp. 153160. https://doi.org/10.1007/s00572-015-0655-2

12. Klavins M., Krigere I. 2016. Natural resource development in Latvia: peat, its composition and new way utilization. Akademiska dzive, 2015/2016, pp. 7-11 (in Latvian).

13. Lazdina D., Bebre I., Dumins K., Skranda I., Lazdina A., Jansons J., Celma S. 2017. Wood ash - green energy production side products as fertilizer for vigorous forest plantations. Agronomy Research, Vol. 15 (2), pp. 468-477.

14. Lazdina D. 2009. Using of waste-water sewage sludge in short rotation willow coppice. Resume of the PhD Thesis, Latvia University of Agriculture, pp. 58.

15. Makiranta P., Hytonen J., Aro L., Maljanen M., Pihlatie M., Potila H., Shurpali N.J., Laine J., Lohila A., Martikainen P.J., Minkkinen K. 2007. Soil greenhouse gas emissions from afforested organic soil croplands and cutaway peatlands. Boreal Environment Research, Vol. 12, pp. 159-175.

16. Makovskis K., Lazdina D., Arsanica A., Solodovniks V. 2016. Mechanical durability and water absorption of pellets made from different tree species - A case study. Agronomy Research, Vol. 14 (1), pp. 134-142.

17. MK noteikumi Nr.570. 2016. Derīgo izrakteṇu ieguves kārtība. http://likumi.lv/doc.php?id=251021. Assesed 17.01.2017. (in Latvian).

18. Ozola I. 2017. Kūdras ieguves un izmantošanas ekonomiskie un sociālekonomiskie aspekti. Akademiska dzive, 2015/2016, 51-64.pp. (in Latvian).

19. Renou-Wilson F., Keane M., McNally G., O’Sullivan, Farrel E.P. 2008. Developing a forest resource on industrial peatland. The BOGFOT programme.

20. Renou F., Farrell,E. P. 2005. Reclaiming peatlands for forestry: the Irish experience. In: Stanturf, J. A. \& Madsen, P. (eds.). Restoration of boreal and temperate forests. CRC Press, London. Pp. 541-557. https://doi.org/10.1201/9780203497784.ch34

21. Renou F., Scallan U., Keane M., Farel E.P. 2007.Early performance of native birch (Betula spp.) planted on cutaway peatlands: Influence of species, stock types and seedlings size. European Journal of Forest Research, Vol. 126, pp. 545554. https://doi.org/10.1007/s10342-007-0175-5

22. Schaible R. 1992. Sitka spruce in the 21st century: establishment and nutrition. Irish Forestry, Vol. 49 (1-2), pp. 10-26.

23. Selin P. 1999. Turvevarojen teollinen käyttö ja suopohjien hyödyntäminen Suomessa. Summary: Industrial use of peatlands and the reuse of cut away areas in Finland., Jyväskylä studies in biological and environmental science 79. 239.

24. Snore A. 2013. Kudras ieguve, 432. (in Latvian). 